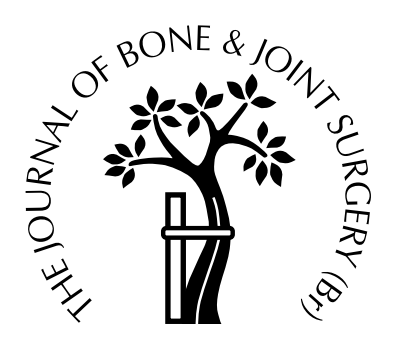

\title{
Hydroxyapatite coated with hepatocyte growth factor (HGF) stimulates human osteoblasts in vitro
}

\author{
Giovanni Zambonin, Claudia Camerino, Giovanni Greco, Vittorio \\ Patella, Biagio Moretti, Maria Grano \\ From the University of Bari, Italy
}

$\mathbf{W}$ e have studied in vitro the effect of a hydroxyapatite (HA) tricalcium phosphate material coated with hepatocyte growth factor (HA-HGF) on cell growth, collagen synthesis and secretion of metalloproteinases (MMPs) by human osteoblasts.

Cell proliferation was stimulated when osteoblasts were incubated with untreated $\mathrm{HA}$ and was further increased after exposure to HA-HGF. The uptake of $\left[{ }^{3} \mathrm{H}\right]$-proline was increased after treatment with $\mathrm{HA}$. When osteoblasts were exposed to HA-HGF, collagen synthesis was increased with respect to HA. The secretion of MMPs in control cells was undetectable, but in HA and HA-HGF cells MMP 2 and MMP 9 were clearly synthesised.

Our results suggest that HA can promote osteoblast activity and that HGF can further increase its bioactivity.

J Bone Joint Surg [Br] 2000;82-B:457-60.

Received 20 July 1998; Accepted after revision 21 May 1999

Osseointegration and early fixation of the components of the prosthesis are of utmost importance for a successful uncemented joint replacement. Several studies ${ }^{1-3}$ have shown that increased micromovement of the prosthesis soon after operation is associated with a higher risk of failure within five years. Hydroxyapatite (HA) coating of the proximal third of the femoral stem and of the acetabular

G. Zambonin, MD

B. Moretti, MD

V. Patella, MD

Dipartimento di Metodologia Clinica e Tecnologie Medico-Chirurgiche,

Sezione di Ortopedia, Università di Bari, Piazza G. Cesare 11, 70124 Bari, Italy.

C. Camerino, $\mathrm{PhD}$, Student

G. Greco, Research Fellow

M. Grano, $\mathrm{PhD}$

Institute of Human Anatomy, University of Bari, Piazza G. Cesare 11, 70124 Bari, Italy.

Correspondence should be sent to Dr G. Zambonin at the Istituto di Anatomia Umana Normale, Policlinico, Piazza G. Cesare, 70124 Bari, Italy.

(C)2000 British Editorial Society of Bone and Joint Surgery 0301-620X/00/39310\$2.00

VOL. 82-B, No. 3, APRIL 2000 component is useful to achieve early fixation and osseointegration with reduction of micromovement. ${ }^{4-8}$ To improve the bioactive properties of HA, bone morphogenetic proteins (BMPs), ${ }^{9-12}$ basic fibroblast growth factor (bFGF) ${ }^{13}$ and transforming growth factor- $\beta$ (TGF- $\beta)^{14}$ have been adsorbed on HA or tricalcium phosphate.

We have performed a study in vitro to evaluate the effects of an HA-tricalcium phosphate material with or without hepatocyte growth factor (HGF) coating on human osteoblasts. HGF is a protein which stimulates the growth of rat hepatocytes. ${ }^{15}$ In epithelial and endothelial cells, it induces cell polarisation and stimulates the formation of tridimensional tubular structures. ${ }^{16}$ Its receptor, a tyrosine kinase encoded by the MET proto-oncogene, is overexpressed in human osteosarcomas and the entity of its expression is directly correlated with growth and malignancy of the tumour. ${ }^{17} \mathrm{HGF}$ has also been found to improve repair of cartilage in $\operatorname{dogs}{ }^{18}$ and to enhance in vitro the anabolic effects of calcitonin on chondrocytes. In bone tissue, HGF is produced by osteoclasts and has effects on both these cells and on osteoblasts, ${ }^{19}$ stimulating chemotactic-orientated migration and DNA synthesis in the former and DNA synthesis in the latter. In this study we have investigated cell proliferation, collagen synthesis and secretion of matrix metalloproteinases (MMPs) which are a family of proteolytic enzymes considered to be important in bone remodelling and in the development of human bone. $^{20,21}$

\section{Materials and Methods}

Biomaterial. We used Triosite (Zimmer, Swindon, UK) which is a porous biphasic material composed of $65 \pm 15 \%$ hydroxyapatite and $35 \pm 15 \%$ tricalcium phosphate with less than $15 \%$ of other phosphates. The $\mathrm{Ca} / \mathrm{P}$ ratio is $2 \pm 0.2$ and the pore size is $400 \pm 150 \mu \mathrm{m}$. The Triosite was crushed into granules $0.5 \mathrm{~mm}^{3}$ in size, sterilised in alcohol, coated with HGF (a gift from P. M. Comoglio of the Institute for Cancer Research, Turin University Medical School) by dipping in a solution of HGF $10^{-8}$ at $4^{\circ} \mathrm{C}$ for 24 hours, air-dried at room temperature and transferred to culture dishes.

The HA or HA-HGF coating was added to already plated osteoblasts. After 48 hours, HA granules were firmly 
attached to the cell monolayers, demonstrating tight contact between HA and osteoblasts.

Human osteoblast cell preparation. Specimens of human bone obtained at a total hip replacement were cleaned of soft tissues, reduced to fragments approximately $2 \mathrm{~mm}$ in size and digested with $0.5 \mathrm{mg} / \mathrm{ml}$ of Clostridium histolyticum neutral collagenase (Sigma Chemical Co, St Louis, Missouri) in phosphate-buffered saline (PBS) for $30 \mathrm{~min}-$ utes at $37^{\circ} \mathrm{C}$. According to Gehron-Robey and Termine, ${ }^{22}$ neutral collagenase is able to remove all the fibroblasts and blood cells from the bone fragments. The bone chips were then washed vigorously three times with Iscove-modified Dulbecco's medium (IMDM; Gibco Ltd, Uxbridge, UK) containing $3.02 \mathrm{~g} / \mathrm{l}$ of sodium bicarbonate and cultured in IMDM supplemented with $10 \%$ fetal calf serum (FSC; Gibco Ltd), $100 \mathrm{IU} / \mathrm{ml}$ of penicillin, $100 \mu \mathrm{g} / \mathrm{ml}$ of streptomycin, $2.5 \mu \mathrm{g} / \mathrm{ml}$ of amphotericin $\mathrm{B}$ and $50 \mathrm{IU} / \mathrm{ml}$ of mycostatin (Eurobio, Paris, France) at $37^{\circ} \mathrm{C}$, in a watersaturated atmosphere containing $5 \% \mathrm{CO}_{2}$. The media were changed every three days. Under these conditions osteoblasts in the explants proliferated and migrated to the culture dishes, reaching confluence within four weeks. Cells were then trypsinised and transferred to appropriate dishes for characterisation and experiment.

Osteoblast characterisation. Human osteoblasts were characterised according to the well-established parameters of alkaline phosphatase activity, production of cAMP in response to $10^{-8} \mathrm{~mol} / \mathrm{l} \mathrm{PTH}$ and synthesis of osteocalcin in response to $10^{-8} \mathrm{~mol} / \mathrm{l}$ of 1,25 -dihydroxy-vitamin $\mathrm{D}_{3}$. The results (not shown) indicate that the cells were well-differentiated osteoblasts. All the experiments were performed in quadruplicate and repeated three times.

Cell proliferation. We carried out proliferation assays in 96-well microtitre plates in serum-free IMDM supplemented with $0.5 \%$ fatty-acid-free bovine serum albumin (BSA; Sigma Chemical Co). In all the experiments the cells were exposed for 48 hours to HA or to HGF-coated HA (HAHGF). As a control group, cells were cultured in IMDM without HA. After 48 hours, osteoblasts were gently washed with PBS, dehydrated with $20 \%$ methanol for ten minutes and stained with $0.5 \%$ crystal violet for five minutes, followed by extensive rinsing. The dye was released from the cells by the addition of $0.1 \mathrm{M} \mathrm{Na}$ citrate in $50 \%$ ethanol. The optical density of the released stain solution was read in a Titertek colorimeter (Microtech Bio-rad, Hercules, California) at a wavelength of $540 \mathrm{~nm}$. The results were expressed as a percentage with respect to untreated control wells \pm SD.

Collagen synthesis. We assessed collagen synthesis by determining the uptake of $\left[{ }^{3} \mathrm{H}\right]$-proline (Amersham International, Amersham, UK) in serum-free IMDM supplemented with $0.5 \%$ BSA. In all the experiments, cells were cultured with HA or HA-HGF for 48 hours. As a control group, cells were cultured in IMDM without HA. After 44 hours $10 \mu \mathrm{l}$ of IMDM containing $5 \mu \mathrm{Ci}$ of $\left[{ }^{3} \mathrm{H}\right]$-proline were added to each well and incubated for a further four hours. A short pulse time was necessary to avoid secretion of $\left[{ }^{3} \mathrm{H}\right]$-hydroxyproline with tropocollagen fibres by the cells. The osteoblasts were then washed with PBS, solubilised in $0.5 \mathrm{ml}$ of $0.1 \%$ sodium dodecyl sulphate (SDS) and precipitated by the addition of $100 \%$ trichloroacetic acid (TCA). After 30 minutes of incubation at $4^{\circ} \mathrm{C}$, TCAprecipitable material was pelleted by centrifugation at $955 \mathrm{~g}$, redissolved in $500 \mu \mathrm{l}$ of $0.1 \%$ SDS and counted in a Beckman 6000 scintillation spectrophotometer (Beckman Instruments Inc, Fullerton, California) after addition of $500 \mu \mathrm{l}$ of distilled water and $9 \mathrm{ml}$ of scintillation fluid (Beckman Instruments Inc). The results were expressed as a percentage with respect to untreated control wells \pm SD.

MMP secretion. We assayed secretion of MMPs by zymography of medium collected from cells cultured without HA (control) and with HA or HA-HGF in serum-free IMDM supplemented with $0.5 \%$ BSA. Each sample was dialysed using spectrapor molecular porous dialysis membranes with 15000 molecular weight cut-off (Pierce, Houston, Texas). The proteins were quantified by a micro BCA protein assay reagent kit (Pierce, Rockford, Illinois). For each sample, $30 \mu \mathrm{g}$ of proteins were loaded on to $8 \% \mathrm{SDS} /$ polyacrylamide gel impregnated with gelatin $(0.5 \mathrm{mg} / \mathrm{ml})$. After electrophoresis at $35 \mathrm{~mA}$ at $4^{\circ} \mathrm{C}$, the gel was washed with $2.5 \%$ Triton-X 100 and incubated for 16 hours at $37^{\circ} \mathrm{C}$ in $40 \mathrm{nM}$ Tris-HC1 buffer ( $\mathrm{pH} 7.5$ ) containing $\mathrm{NaC} 10.2 \mathrm{M}$ and $\mathrm{CaCl}_{2} 10 \mathrm{mM}$. Clear bands, identifying the position of the MMPs, were visualised on the dark-blue background after staining with $0.25 \%$ Coomassie Blue R250 and destaining with $50 \%$ methanol and $10 \%$ acetic acid.

Statistical analysis. Since our data were normally distributed but without equal variance among the different groups, we used the Kruskal-Wallis analysis of variance (ANOVA) to determine significance between the different treatments. When significance was found, a Dunn multiple comparison test was used to establish where the difference occurred. We set a level of significance of $\mathrm{p}<0.05$.

\section{Results}

Cell proliferation. The proliferation of osteoblasts was significantly stimulated after exposure to HA granules with respect to the untreated control cells (Fig. 1). In the HAHGF treated cells there was a further and significant increase compared with both control cells and HA-coated cells.

Collagen synthesis. Figure 2 shows that treatment with HA and HA-HGF significantly stimulated collagen synthesis compared with untreated control cells. The uptake of $\left[{ }^{3} \mathrm{H}\right]-$ proline in the HA-HGF-treated cells was also significantly increased compared with HA-treated cells.

MMP secretion. In control cells there was no secretion of MMPs. In the presence of HA and HA-HGF, however, there was clear evidence of secretion of two different MMPs at $72 \mathrm{kDa}$ (gelatinase-A, MMP 2) and $92 \mathrm{kDa}$ (gelatinase-B, MMP 9). There was no significant difference 


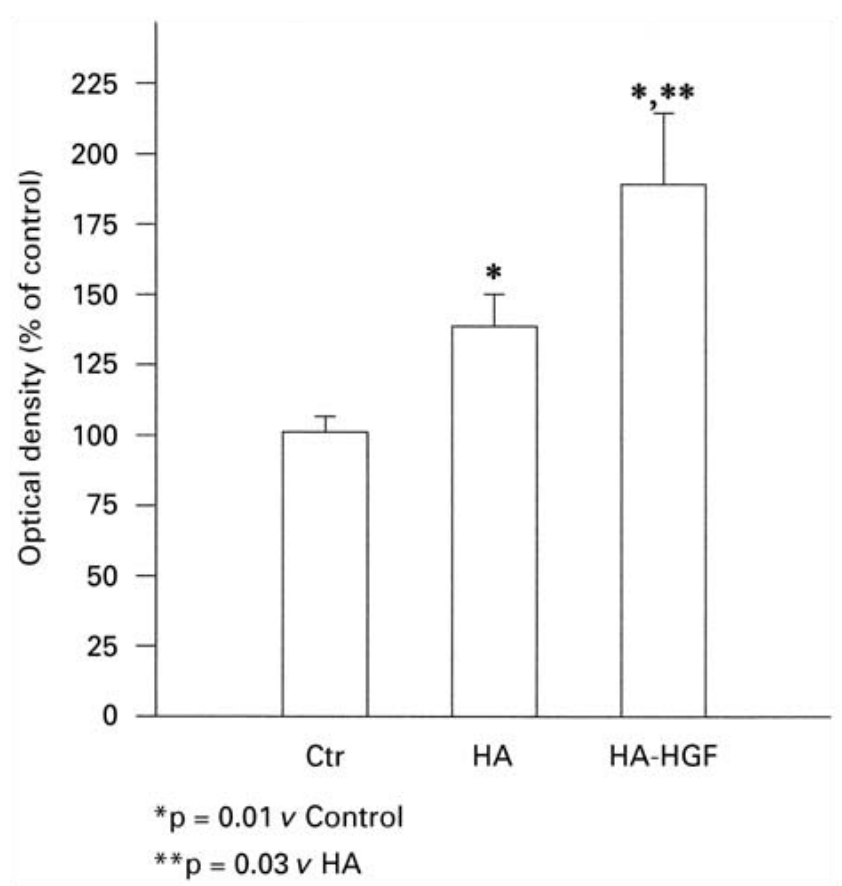

Fig. 1

The effect of HA and of HA-HGF on the proliferation of human osteoblasts. The results are expressed as the percentage of optical density at a wavelength of $540 \mathrm{~nm}$ with respect to untreated control wells $\pm \mathrm{SD}$.

in the amount of MMP secreted in the HA and HA-HGF cells (Fig. 3).

\section{Discussion}

Hydroxyapatite and tricalcium phosphate are widely used in orthopaedic surgery for their biocompatibility and bioactivity. ${ }^{2324}$ We have used a commercial HA-tricalcium phosphate material (Triosite) which was coated with HGF and tested in vitro for its effect on cell growth, collagen synthesis and MMP production of osteoblasts. HA significantly stimulated cell proliferation with respect to control cells while in the presence of HA-HGF it reached higher values with respect to HA (Fig. 1), indicating that HGF is able to increase the ability of HA to stimulate osteoblast proliferation. After exposure to HA, increased collagen synthesis was found with respect to the control cells (Fig. 2). In the HA-HGF-treated group, $\left[{ }^{3} \mathrm{H}\right]$-proline was significantly increased with respect to HA which suggested a stimulatory effect of HGF. The increased cell proliferation and collagen synthesis seen in the presence of HA-HGF could be explained by the possible role of HGF in bone remodelling. HGF is a growth factor which has been found to have autocrine-paracrine effects on bone cells; $;{ }^{19}$ it is produced by osteoclasts and promotes DNA synthesis, increases c-Src activity and has a strong chemotactic effect. In osteoblasts, HGF stimulates DNA synthesis and, when used with HA, collagen synthesis (Fig. 2). HGF also has neo-angiogenic activity, ${ }^{16}$ which is of considerable impor-

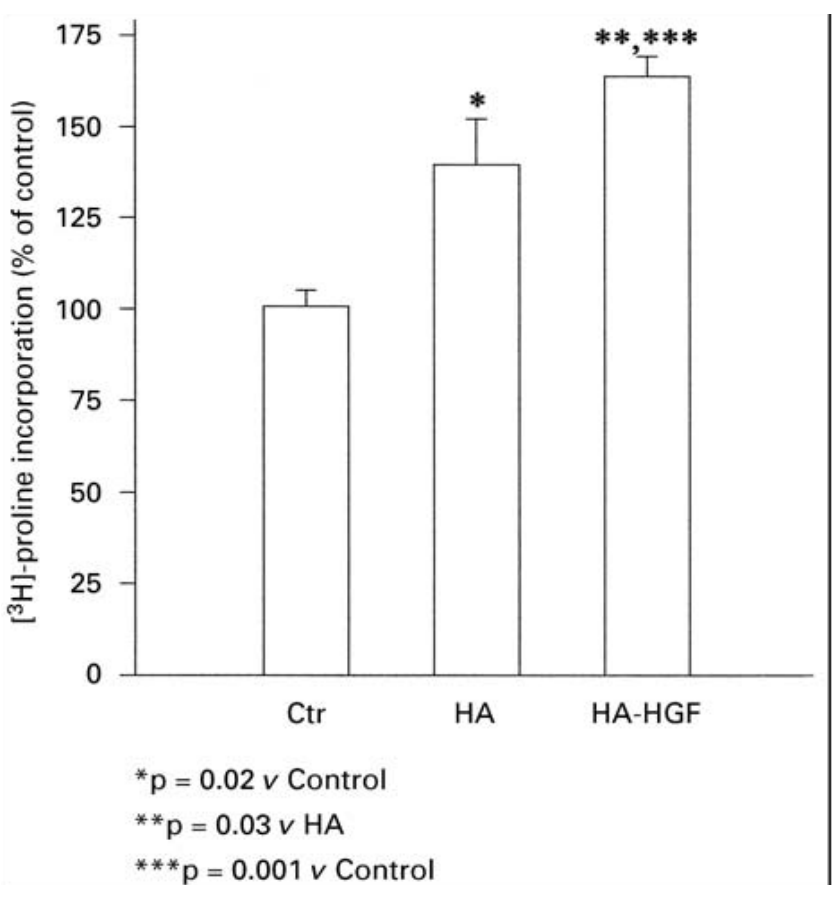

Fig. 2

The effect of HA and HA-HGF on the synthesis of collagen in human osteoblasts measured by the uptake of $\left[{ }^{3} \mathrm{H}\right]$-proline. The results are expressed as percentage with respect to untreated control wells \pm SD.

tance in regard to the role of the newly formed capillary network in the formation and organisation of the Haversian system. In normal conditions, HGF may influence bone remodelling by the stimulation of the recruitment of osteoclasts, proliferation and bone resorption by an autocrineparacrine mechanism and then proliferation of osteoblasts and the synthesis of collagen. HA-HGF may therefore be of value as a prosthetic coating since increased recruitment of osteoclasts could help in the removal of non-viable bone produced by reaming bone and the increased osteoblast activity may help to fill the gap between the prosthesis and the bone thereby obtaining earlier osseointegration.

Secretion of MMPs was not detectable under control conditions, whereas in cells treated with HA and HA-HGF, they were clearly evident in similar amounts (Fig. 3). MMPs are a family of proteolytic enzymes expressed by both osteoclasts and osteoblasts ${ }^{25}$ including collagenases, gelatinases A and B, and stromelysins. In osteoclasts, they are considered to be important in bone resorption while their precise role in osteoblasts has not yet been established ${ }^{26}$ but it is thought that they are involved in bone remodelling, especially during skeletal growth and development and in the pathological resorption which occurs with bone metastasis. ${ }^{27}$ In a study of collagenase expression during mouse embryogenesis, Mattot et $\mathrm{al}^{28}$ found that MMP was expressed only at the onset of bone formation, indicating a role of these enzymes in bone synthesis. In normal human bone, collagenase expression was found in cells synthesising matrix and in lining cells and the strong- 


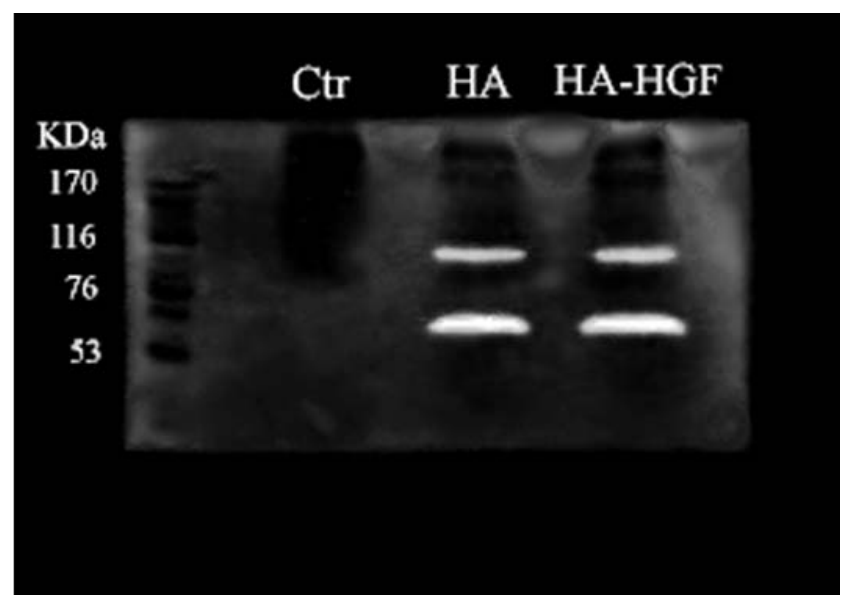

Fig. 3

Zymograph of medium collected from osteoblasts cultured in control conditions and with HA and HA-HGF showing the presence of MMP 2 and MMP 9 in both HA- and HA-HGF-treated groups.

est signal was seen in areas of new formation of matrix. ${ }^{25}$ These findings indicate that in normal bone an increased synthesis of MMPs in osteoblasts could be related to increased bone synthesis. The increased production observed in HA- and HA-HGF-treated osteoblasts may reflect the ability of this biomaterial to activate osteoblasts toward bone synthesis. In our experiments, HA-HGF was not able to increase the production of MMPs with respect to $\mathrm{HA}$, indicating that HGF is probably ineffective in promoting its synthesis and acts mainly on cell replication and collagen synthesis. This selective effect has been reported also in other osteogenic growth factors such as TGF- $\beta$ which increases collagen synthesis and cell proliferation but inhibits the level of MMPs in osteoblasts. ${ }^{29}$ Our results reflect the clinical evidence that $\mathrm{HA}$ is helpful in obtaining better osseointegration of prostheses. ${ }^{7}$ In vitro, the coating with HGF was effective in further improving the bioactivity of HA but these promising results require to be confirmed by studies in vivo.

No benefits in any form have been received or will be received from a commercial party related directly or indirectly to the subject of this article.

\section{References}

1. Søballe K, Toksvig-Larsen S, Gelineck J, et al. Migration of hydroxyapatite coated femoral stems: a roentgen stereophotogrammetric study. J Bone Joint Surg [Br] 1993;75-B:681-7.

2. Kärrholm J, Borssén B, Löwenhielm G, Snorrason F. Does early micromotions of femoral stem prostheses matter? 4-7-year stereoradiographic follow-up of 84 cemented hip prostheses. J Bone Joint Surg [Br] 1994;76-B:912-7.

3. Kärrholm J, Herberts P, Hultmark P, et al. Radiostereometry of hip prostheses: review of methodology and clinical results. Clin Orthop 1997;344:94-110.

4. Moilanen T, Stocks GW, Freemann MAR, et al. Hydroxyapatite coating of an acetabular prosthesis: effect on stability. J Bone Joint Surg [Br] 1996;78-B:200-5.

5. Geesink RGT, Hofnagels NHM. Six-year results of hydroxyapatitecoated total hip replacement. J Bone Joint Surg [Br] 1995; 77-B:53447
6. D'Antonio JA, Capello WN, Manley MT. Remodeling of bone around hydroxyapatite-coated femoral stems. J Bone Joint Surg [Am] 1996;78-A:1226-34

7. Capello WN, D'Antonio JA, Feinberg JR, Manley MT. Hydroxyapatite-coated total hip femoral components in patients less than fifty years old: clinical and radiographic results after five to eight years of follow-up. J Bone Joint Surg [Am] 1997;79-A:1023-9.

8. Donnelly WJ, Kobayashi A, Freeman MA, et al. Radiological and survival comparison of four methods of fixation of a proximal femoral stem. J Bone Joint Surg [Br] 1997;79-B:351-60.

9. Wang EA, Rosen V, D'Alessandro JS, et al. Recombinant human bone morphogenetic protein induces bone formation. Proc Natl Acad Sci USA 1990;87:2220-4.

10. Ono I, Ohura T, Murata M, et al. A study on bone induction in hydroxyapatite combined with bone morphogenetic protein. Plast Reconstr Surg 1992;90:870-9.

11. Cook SD, Rueger DC. Osteogenic protein-1, biology and applications. Clin Orthop 1996; 324:29-37

12. Gao T, Lindholm TS, Marttinen A, Urist MR. Composites of bone morphogenetic protein (BMP) and type IV collagen, coral-derived coral hydroxyapatite and tricalcium phosphate ceramic. Int Orthop 1996;20:321-5.

13. Wang JS, Aspenberg P. Basic fibroblast growth factor promotes bone ingrowth in porous hydroxyapatitie. Clin Orthop 1996;333:252-60.

14. Lind M, Overgaard S, Soballe $K$, et al. Transforming growth factorbeta 1 enhances bone healing to unloaded tricalcium phosphate coated implants: an experimental study in dogs. J Orthop Res 1996;14:343-50.

15. Nakamura T, Teramoto H, Ichihara A. Purification and characterization of a growth factor from rat platelets for mature parenchymal hepatocytes in primary cultures. Proc Natl Acad Sci USA 1986;83:6489-93.

16. Bussolino F, Di Renzo MF, Ziché M, et al. Hepatocyte growth factor is a potent angiogenic factor which stimulates endothelial cell motility and growth. J Cell Biol 1992;119:629-41.

17. Scotlandi K, Baldini N, Oliviero M, et al. Expression of Met/ hepatocyte growth factor receptor gene and malignant behaviour of musculoskeletal tumors. Am J Pathol 1996;149:1209-19.

18. Wakitani S, Imoto K, Kimura T, et al. Hepatocyte growth factor facilitates cartilage repair: full thickness articular cartilage defect studied in rabbit knees. Acta Orthop Scand 1997;68:474-80.

19. Grano M, Galimi F, Zambonin G, et al. Hepatocyte growth factor is a coupling factor for osteoclasts and osteoblasts in vitro. Proc Natl Acad Sci USA 1996;93:7644-8.

20. Rifas L, Fausto A, Scott MJ, Avioli LV, Welgus HG. Expression of metalloproteinases and tissue inhibitors of metalloproteinases in human osteoblast-like cells: differentiation is associated with repression of metalloproteinase biosynthesis. Endocrinology 1994;134:213-21.

21. Bord S, Horner A, Hembry RM, Reynolds JJ, Compston JE. Distribution of matrix metalloproteinases and their inhibitor, TIMP-1, in developing human osteophytic bone. J Anat 1997;191:39-48.

22. Gehron-Robey PG, Termine JD. Human bone cells in vitro. Calcif Tissue Int 1985;37:453-60.

23. Oonishi H, Ywaky I, Kin N, et al. Hydroxyapatite in revision of total hip replacements with massive acetabular defects: 4- to 10-year clinical results. J Bone Joint Surg [Br] 1997;79-B:87-92.

24. Søballe K, Overgaard S. Editorial. The current status of hydroxyapatite coating. J Bone Joint Surg [Br] 1996;78-B:689-91.

25. Bord S, Horner A, Hembry RM, Reynolds JJ, Compston JE. Production of collagenase by human osteoblasts and osteoclasts in vivo. Bone 1996;19:35-40.

26. Krane SM. Is collagenase (matrix metalloproteinase-1) necessary for bone and other connective tissue remodeling? Clin Orthop 1995;313:47-53.

27. Ohishi K, Fujita N, Morinaga Y, Tsuruo T. H-31 human breast cancer cells stimulate type 1 collagenase production in osteoblast-like cells and induce bone resorption. Clin Exp Metastasis 1995;13:287-95.

28. Mattot V, Raes MB, Henriet $\mathbf{P}$, et al. Expression of interstitial collagenase is restricted to skeletal tissue during mouse embryogenesis. J Cell Sci 1995;108:529-35.

29. Canalis E. Growth factors and the skeleton. In: Genant, Guglielmi and Jergas, eds. Bone densitometry and osteoporosis. Berlin: SpringerVerlag, 1998:61-73. 